\section{Implementasi Uji Mutu Pelaksanaan Pekerjaan Konstruksi Paket Pembangunan Jalan Batas Kec. Siding/Seluas - Batas Kecamatan Sekayam/Entikong (Myc) Provinsi Kalimantan Barat}

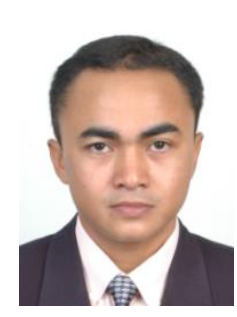

\section{Deddy Junaidi}

Penulis adalah pegawai PNS pada Kementerian Pekerjaan Umum dan Perumahan Rakyat Balai Direktorat Jenderal Bina Marga pada Unit Kerja Besar Pelaksanaan Jalan Nasional XI (Kalsel, Kalteng, Kalbar), Bidang Pembangunan dan Pengujian, sebagai Kepala Seksi Pembangunan dan Pengujian Jalan BBPJN XI.d3ddybalai11@gmail.com

\section{Pendahuluan}

Balai Besar Pelaksanaan Jalan Nasional XI mempunyai tugas dan fungsinya sebagai pengendalian dan pengawasan konstruksi pelaksanaan pembangunan jaringan jalan nasional termasuk jalan bebas hambatan dan penyesuaian kontrak pelaksanaan konstruksi.

Dalam kegiatan tersebut harus dilakukan monitoring dan evaluasi dalam pelaksanaannya untuk pencapaian mutu konstruksi jalan yang dipersyaratkan, baik fisik maupun non fisik dengan penekanan terhadap tertib penyelenggaraan dan hasil pekerjaan konstruksi yang meliputi aspek perencanaan pekerjaan konstruksi, pengadaan, manajemen pengendalian, pelaksanaan kontrak yang didukung kompetensi penyelenggara. (Permen 04/PRT/M/2009)

Penyelenggara pekerjaan konstruksi wajib mewujudkan hasil pekerjaan konstruksi yang handal dan bermanfaat dengan memenuhi ketentuan tertib penyelenggaraan pekerjaan konstruksi, seperti persyaratan keselamatan umum, konstruksi bangunan, mutu hasil pekerjaan, mutu bahan dan/atau komponen bangunan, dan mutu peralatan sesuai dengan standar atau norma yang berlaku. Disamping itu tetap mengutamakan keamanan, keselamatan, dan kesehatan tempat kerja konstruksi sesuai dengan peraturan perundangundangan yang berlaku.

Dalam pelaksanaan proyek konstruksi, sasaran pengelolaan proyek (project management) disamping biaya dan jadwal adalah pemenuhan persyaratan mutu. Dalam hubungan ini, suatu peralatan, material dan cara kerja diangap memenuhi persyaratan mutu apabila dipenuhi semua persyaratan yang ditentukan dalam kriteria dan spesifikasi. Dengan demikian, instalasi/bangunan yang

\begin{abstract}
Penulisan ini bertujuan untuk (1) Mengetahui implementasi uji mutu pelaksanaan pekerjaan konstruksi pada Paket Pembangunan Jalan Batas Kec. Siding/Seluas - Batas Kecamatan Sekayam/Entikong (MYC) Provinsi Kalimantan Barat, dan (2) Mengetahui ketidaksesuaian; akar penyebab masalah; acuan/aturan dalam pelaksanaan uji mutu konstruksi pada paket tersebut disertai saran perbaikan. Setelah monitoring pelaksanaan uji mutu konstruksi pada paket tersebut, didapatkan bahwa (1) Pelaksanaan sistem manajemen kesehatan dan keselamatan kerja pada sistem kesehatan dan keselamatan kerja dalam kondisi yang baik. Hal tersebut diwujudkan dalam bentuk kinerja penerapan penyelenggaraan kesehatan dan keselamatan kerja berdasarkan Peraturan Menteri PU No. 9 tahun 2008, (2) Ketidaksesuaian, akar penyebab dan saran perbaikannya.

Kata kunci: Uji mutu konstruksi, pekerjaan konstruksi jalan

www.buletinppi.ulm.ac.id
\end{abstract}

dibangun atau produk yang dihasilkan, yang terdiri dari komponen peralatan dan material yang memenuhi persyaratan mutu, dapat diharapkan berfungsi secara memuaskan selama kurun waktu tertentu atau dengan kata lain siap untuk dipakai (fitness for use). Dan untuk mencapai tujuan tersebut secara efektif dan ekonomis tidak hanya diperlukan pemeriksaan di tahap akhir sebelum diserahterimakan (FHO) kepada pemilik proyek/konsumen, tetapi juga diperlukan serangkaian tindakan sepanjang siklus proyek mulai dari penyusunan program, perencanaan, pengawasan, pemeriksanaan dan pengendalian mutu. Kegiatan tersebut dikenal dengan penjaminan mutu (Quality Assurance-QA)

Quality Control dalam pekerjaaan konstruksi memegang peranan yang cukup penting, karena dapat menentukan kualitas dari hasil pelaksanaan pekerjaan. Pengawasan terhadap mutu pekerjaan yang baik akan menghasilkan kualitas pekerjaan yang baik pula. Hal ini akan menumbuhkan kepercayaan Owner (pemilik proyek) kepada kontraktor pelaksana dan pengawas proyek.

Quality Contol juga membuat laporan pemeriksaan kepada quality assurance. Oleh karena itu, quality control membutuhkan pengalaman dan juga pemahaman yang baik tentang pengendalian mutu melalui spesifikasi teknik yang digunakan dan metode praktis dalam pemeriksaan mutu pekerjaan. Untuk lebih mengetahui tentang tugas dan tanggung jawab utama seorang quality control dapat dilihat di bawah ini. 


\section{Metode dan Literatur}

Pelaksanaan Uji Mutu ini dibuat sebagai pedoman umum Tim Uji Mutu dan pihak-pihak terkait lainnya, agar mempunyai pemahaman yang sama tentang pendekatan, sasaran dan tujuan uji mutu, kriteria pemilihan paket, lingkup kegiatan, metode pengambilan dan pengujian sampel, sampai dengan pembuatan dan penyampaian laporan, sehingga didalam pelaksanaannya terarah dan terkendali.

\section{Dasar Pelaksanaan}

1. Berdasarkan Peraturan Menteri Pekerjaan Umum No. 04/PRT/M/2009 tentang Sistem Manajemen Mutu (SMM) Ditjen Bina Marga.

2. Berdasarkan Permen PUPERA No. 34/PRT/M/2015 tentang Organisasi dan Tata Kerja Unit Pelaksana Teknis Kementerian Pekerjaan Umum dan Perumahan Rakyat, (dinyatakan tetap berlaku sepanjang tidak bertentangan dan/atau belum diubah atau diganti dengan peraturan pelaksanaan yang baru).

3. Berdasarkan Permen PUPERA No. 20/PRT/M/2016 tentang Organisasi dan Tata Kerja Unit Pelaksana Teknis Kementerian Pekerjaan Umum dan Perumahan Rakyat.

4. Berdasarkan Surat Keputusan Kepala Balai Pelaksanaan Jalan Nasional XI No.005/KPTS/SATKER/Bz/2017 tanggal 2 Pebruari 2017 tentang Monitoring Mutu Pelaksanaan Pekerjaan/Uji Mutu dan Laboratorium.

\section{Pedoman Kegiatan Uji Mutu}

Pedoman mutu dikembangkan dan diterapkan pada tingkat Departemen, mencakup kebijakan mutu konstruksi pimpinan Departemen, struktur organisasi yang berkaitan dengan SMM, ketentuan tentang pengembangan dan penerapan SMM pada tingkat Direktorat Jenderal dan Unit Pelaksana Konstruksi, serta batasan bagi penerapan SMM konstruksi pada tingkat Direktorat Jenderal dan Unit Pelaksana Konstruksi.

Manual Mutu dikembangkan berdasar Pedoman Mutu pada tingkat Departemen, terkait kekhususan masingmasing Direktorat Jenderal. Manual Mutu harus mengidentifikasi seluruh elemen yang dipersyaratkan dalam SMM SNI 19.9001.2001

Prosedur mutu berisi petunjuk pelaksanaan kegiatan atau aktivitas yang berkaitan dengan penjaminan mutu konstruksi di lingkungan Direktorat Jenderal terkait. Minimal mencakup mengenai Pejabat yang membuat, memeriksa dan mengesahkan Prosedur Mutu;

- Riwayat perubahan Prosedur Mutu;

- Daftar distribusi Prosedur Mutu;

- Lingkup penerapan dari Prosedur Mutu;

- Referensi atau acuan yang digunakan dalam Prosedur Mutu;

- Tahapan proses, aktivasi, atau kegiatan dari Prosedur Mutu;
- Daftar lampiran berupa format Catatan Mutu yang merupakan pencatatan terhadap pelaksanaan kegiatan dari prosedur Mutu.

Dalam rangka penerapan SMM konstruksi yang mengacu kepada standar SMM SNI 19.9001:2001 maka terdapat prosedur mutu yang minimal wajib dimiliki yaitu :

- Prosedur Audit Mutu Internal;

- Prosedur Pengendalian Dokumen dan Data;

- Prosedur Pengendalian Produk yang tidak sesuai;

- Prosedur Tindakan Perbaikan; dan

- Prosedur Tindakan Pencegahan

Rencana Mutu berisi rencana pelaksanaan kegiatan proyek dalam rangka penjaminan mutu konstruksi yang dihasilkan.

Rencana Mutu harus mengidentifikasiksi :

- Pejabat yang membuat, memeriksa dan mengesahkan rencana Mutu;

- Riwayat perubahan rencana Mutu;

- Daftar distribusi Rencana mutu;

- Lingkup penerapan Rencana Mutu; dan

- Referensi atau acuan yang digunakan dalam Rencana Mutu.

Terdapat dua jenis Rencana Mutu yaitu :

Rencana Mutu Proyek (RMP) adalah dokumen SMM konstruksi yang disusun oleh Unit Pelaksana sebagai pengguna barang / jasa dalam rangka menjamin mutu konstruksi bidang Pekerjaan Umum. Dokumen RMP digunakan sebagai panduan pelaksanaan pemantauan dan peninjauan terhadap pelaksanaan kegiatan proyek dibandingkan dengan ketentuan dan persyaratan yang telah ditetapkan sebelumnya dalam perencanaan program.

RMP minimal mencakup : kebijakan proyek; informasi proyek; struktur organisasi proyek; lingkup kegiatan proyek; jadwal pelaksanaan kegiatan; daftar peralatan kerja; bagan alir pelaksanaan kegiatan; sistem manajemen mutu proyek; dan Daftar Simak.

Rencana Mutu Kontrak (RMK) adalah dokumen SMM konstruksi yang disusun oleh Penyedia barang / jasa untuk setiap kontrak pekerjaan, digunakan untuk menjamin bahwa spesifikasi teknis yang melekat pada kontrak antara Penyedia Barang/Jasa dengan Pengguna Barang/Jasa sebagai wakil dari Departemen Pekerjaan Umum dipenuhi sebagaimana mestinya.

RMK minimal mencakup: informasi pengguna dan penyedia jasa; bagan organisasi pelaksana pekejaan termasuk organisasi pengguna barang/ jasa serta konsultan pengawas; uraian tugas \& tanggung jawab pelaksana pekerjaan; prosedur pelaksanaan pekerjaan; prosedur instruksi kerja; bagian alir kegiatan pokok; gambar kerja (shop drawing); daftar bahan; daftar peralatan; jadwal kegiatan; \& jadwal inspeksi; jadwal mobilisasi bahan, peralatan utama dan personil inti; lembar kerja dan daftar simak. 


\section{Pendekatan Kegiatan Uji Mutu}

1. Kegiatan ini hanya dalam rangka pembinaan mutu internal, untuk bahan perbaikan mutu pekerjaan jalan dan jembatan kedepan, jadi sifatnya bukan pemeriksaan apalagi untuk mencari-cari kesalahan, tujuannya hanya mengarahkan agar kontraktor/konsultan bekerja sesuai koridor spesifikasi teknis.

2. Agar kegiatan ini berjalan dengan lancar perlu dijalin kerja sama yang baik antar (Satker/PPK, Konsultan, Kontraktor dan Tim Uji Mutu).

3. Kami berharap dengan kerja sama yang baik, tidak akan terjadi mis-informasi yang berakibat laporan menjadi keliru sehingga merugikan pihak lain.

4. Dengan adanya kegiatan ini tidak berarti dan sertamerta mengurangi/menghilangkan peran tugas dan tanggung jawab Satker/PPK, Konsultan dan Kontraktor, baik terhadap fisik maupun keuangan sesuai ketentuan dan peraturan-peraturan berlaku yang melekat padanya.

5. Kegiatan ini semata-mata tidak hanya untuk pembelajaran tetapi juga sebagai pembinaan serta evaluasi pelaksanaan pekerjaan kontraktual maupun swakelola/rutin secara internal.

\section{Tujuan dan Sasaran Uji Mutu}

1. Melaksanakan salah satu Tugas pokok dan fungsi Balai Besar Pelaksana Jalan Nasional XI yaitu melaksanakan Pembinaaan terhadap Satker/PPK, Kontraktor dan Konsultan.

2. Agar didalam pelaksanaan pekerjaan baik $Q A P$ (Quality Assurance Plan) tanggung jawab konsultan dan QCP (Quality Control Plan) tanggung jawabnya kontraktor, selalu berkesesuaian dengan dokumen kontrak (Spesifikasi seksi 1.21 Manajemen Mutu).

3. Untuk bahan evaluasi perbaikan mutu pekerjaan Jalan dan Jembatan kedepan.

4. Dapat dijadikan Raport Satker/PPK, Kontraktor dan Konsultan Supervisi.

Kriteria Pemilihan Paket Pekerjaan Uji Mutu:

1. Paket-paket proyek yang akan $\mathrm{PHO} /$ Proses $\mathrm{PHO}$

2. Paket-paket proyek yang rawan capaian mutu dan waktu,

3. Paket-paket MYC,

4. Paket-paket yang nilai kontrak > Rp. 20 Milyar (Long Segment),

5. Paket-paket permintaan/masukan dari Satker/PPK, Penyedia Jasa atau masyarakat untuk dilakukan uji mutu.

Lingkup Kegiatan Tim Uji Mutu Meliputi :

1. Monitoring teknis baik masalah metode kerja maupun mutu hasil pekejaan.

2. Monitoring pelaksanaan pekerjaan yang berhubungan dengan teknis pengendalian mutu oleh konsultan
(QAP) maupun yang dilaksanakan oleh Kontraktor (QCP).

3. Melakukan test mutu pekerjaan, langsung uji lapangan dan sekalian pengambilan sample sesuai kebutuhan untuk uji laboratorium antara lain:

a. Untuk Timbunan Tanah: dilakukan test kepadatan uji lapangan (Sandcone, dengan jumlah titik yang nanti disepakati bersama)

b. Untuk Agregat A / B / S : dilakukan test kepadatan uji lapangan (Sandcone, dengan jumlah titik yang nanti disepakati bersama) dan mengambil sample agregat, hanya untuk test gradasi dilaboratorium BBPJN VII Banjarmasin mengingat waktu yang terbatas.

c. Untuk Aspal Hotmix (AC-Base/AC-BC/AC-WC, HRS-Base/HRS-WC):

c.1. Dibatasi hanya untuk test ketebalan dan uji kepadatan/density (Coredrill, dengan jumlah titik yang ditentukan/disepakati 5 -10 titik).

c.2. Jika saat uji petik AMP berproduksi dan/atau pelaksanaan penghamparan aspal sedang berjalan, maka diambil sample gembur dibelakang finisher atau di AMP untuk pengujian kadar aspal dilaboratorium (Ekstraksi).

d. Untuk pekerjaan Beton :

d.1. Jika saat uji petik sedang dalam pelaksanaan cor beton lakukan tes kadar air lapangan (Slump-test)

d.2. Untuk cek kuat tekan beton dilakukan dengan (Hammer-test, yang dapat mewakili tiap kegiatan pekerjaan beton)

d.3. Test core inti beton jika diperlukan/disepakati.

Metode Pengujian Sample :

1. Pengujian analisa saringan agregat halus dan kasar berdasarkan (SNI 03-1968-1990)

2. Pengujian kepadatan lapangan dengan alat konus pasir berdasarkan (SNI 03-2828-1992)

3. Kepadatan kering maksimum berdasarkan (SNI 1743:2008)

4. Cara uji keausan agregat dengan masin abrasi los angeles berdasarkan (SNI 2417-2008)

5. Density aspal berdasarkan (SNI 03-6757-2002)

6. Cara Slump Beton berdasarkan (SNI 1972:2008)

7. Kuat Tekan Beton berdasarkan (SNI 03-1974-1990)

8. Pengujian kadar aspal cara senterifius berdasarkan (SNI 03-6894-2002)

9. Dan lain-lain sesuai yang tercantum dalam spesifikasi 2010 revisi 3

Hasil uji mutu dapat digunakan antara lain:

1. Sebagai syarat untuk dapat dilakukan pembayaran terhadap pekerjaan yang telah diterima hasil pengujian quality control atau pengendalian mutu.

2. Sebagai syarat untuk disetujui tahapan pekerjaan selanjutnya. 
3. Mengacu pada syarat dari spesifikasi teknik yang digunakan.

4. Bagian dari penjaminan mutu (quality assurance).

5. Sebagai pertanggung jawaban kontraktor terhadap hasil pekerjaan saat masa PHO (Provisional Hand Over) dan FHO (Final Hand Over)

Peraturan Mengenai Uji Mutu Konstruksi

Permen 04/PRT/M/2009 diterbitkan untuk memudahkan Unit Kerja/Satuan Kerja/Unit Pelaksana Kegiatan, serta Penyedia Barang/Jasa dalam melaksanakan tugas pemerintahan (TUSI) di bidang Pekerjaan Umum (sesuai Permen PUPR 15/PRT/M/2015) agar tercapai kinerja yang direncanakan secara akuntabel, efisien dan efektif dalam rangka mewujudkan "tata pemerintahan yang baik (Good Governance)"

\section{Peraturan Menteri PU No. 9 Tahun 2008}

Sistem Manajemen Keselamatan dan Kesehatan Kerja (SMK3) adalah bagian dari sistem manajemen secara keseluruhan yang meliputi struktur organisasi, perencanaan, tanggung jawab, pelaksanaan, prosedur, proses dan sumber daya yang dibutuhkan bagi pengembangan penerapan, pencapaian, pengkajian dan pemeliharaan kebijakan keselamatan dan kesehatan kerja guna terciptanya tempat kerja yang selamat, aman, efisien dan produktif.

SMK3 konstruksi bidang pekerjaan umum adalah SMK3 pada sektor jasa konstruksi yang berhubungan dengan kepentingan umum (masyarakat) antara lain pekerjaan konstruksi: jalan, jembatan, bangunan gedung fasilitas umum, sistem penyediaan air minum dan perpipaannya, sistem pengolahan air limbah dan perpipaannya, drainase, pengolahan sampah, pengaman pantai, irigasi, bendungan, bendung, waduk, dan lainnya.

\section{Peraturan Pemerintah (PP) No. 50 Tahun 2012}

SMK3 adalah bagian dari sistem manajemen perusahaan secara keseluruhan dalam rangka pengendalian risiko yang berkaitan dengan kegiatan kerja guna terciptanya tempat kerja yang aman, efisien, dan produktif.
Mengapa perlu adanya SMK3. Sistem manajemen diperlukan untuk meningkatkan upaya K3 yang dijalankan dalam perusahaan agar berjalan secara efisien dan efektif.

\section{Penilaian Kinerja Penerapan Penyelenggaraan SMK3}

Untuk mengetahui Kinerja Penerapan Penyelenggaraan SMK3 Proyek Peningkatan Struktur Jalan Batas Kota Muara Tewe Kandui, dilakukan Monitoring dan Evaluasi SMK3 Konstruksi (Monev SMK3). Maksud Penyelenggaraan Monev SMK3 adalah untuk mengukur tingkat penyelenggaraan SMK3 dalam pemenuhan syaratsyarat keamanan, keselamatan dan kesehatan kerja pada tempat kegiatan konstruksi dan bertujuan untuk pembinaan penerapan SMK3 Konstruksi di lingkungan Kementerian PU. Monev dilakukan kepada pihak pengguna jasa, yaitu Satker dan PPK serta pihak penyedia jasa.

\section{Monev Pengguna Jasa (Satker):}

1. Satker menerapkan SMK3 Konstruksi Bidang PU secara penuh mengacu pada Permen PU No. 09/PRT/M/2008 tentang Pedoman Sistem Manajemen Keselamatan Dan Kesehatan Kerja (K3) Konstruksi Bidang Pekerjaan Umum

2. Persyaratan K3 dimasukkan dalam Dokumen Pemilihan Penyedia Jasa oleh Pokja Satker

3. Satker sudah mempunyai dan memasang Kebijakan K3 dan Pakta Komitmen K3 Kementerian PU, dipasang di tempat yang mudah dibaca dan disosialisasikan kepada unit kerja/staf di bawah kendali Satker

4. Satker mempunyai Prosedur Teknis tentang Pelaksanaan SMK3 Konstruksi yang diterbitkan oleh Pejabat Eselon I, sesuai Permen PU No. 09/PRT/M/2008 Pasal 7 ayat (1)

5. Satker mempunyai Petunjuk Teknis Pelaksanaan Monitoring dan Evaluasi Penyelenggaraan SMK3 Konstruksi

\section{Hasil dan Pembahasan}

Hasil pelaksanaan uji mutu konstruksi (sampel) pada Paket Pembangunan Jalan Batas Kec. Siding/Seluas - Batas Kecamatan Sekayam/Entikong (MYC) Provinsi Kalimantan Barat ditunjukkan sebagaimana dalam Tabel 1 berikut:

Tabel 1 : Hasil pelaksanaan uji mutu konstruksi

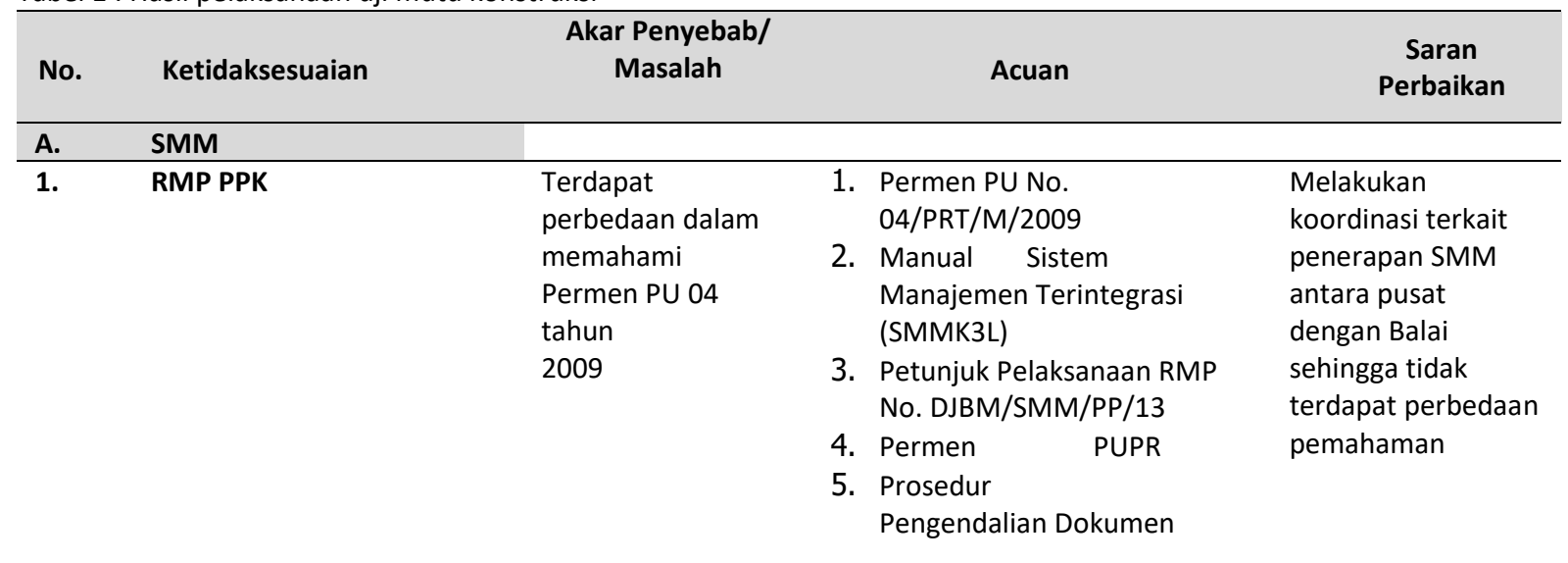




\begin{tabular}{|c|c|c|c|}
\hline a. & $\begin{array}{l}\text { Lembar pengesahan belum } \\
\text { ditanda tangan pada } \\
\text { "Pemeriksa" } \\
\text { "Pengesah" }\end{array}$ & $\begin{array}{l}\text { 1. Lampiran I, Bab 7.1.2.2. : } \\
\text { Atasan Langsung dari Kepala } \\
\text { Satuan Kerja/SNVT/SKS/PPK } \\
\text { bertanggung jawab atas } \\
\text { pengesahan pelaksanaan } \\
\text { RMP dan digunakan sebagai } \\
\text { dokumen monitoring } \\
\text { kegiatan }\end{array}$ & $\begin{array}{l}\text { Lembar Pengesahan } \\
\text { agar segera } \\
\text { ditandatangani, } \\
\text { kemudian } \\
\text { dilanjutkan dengan } \\
\text { pengendalian } \\
\text { dokumen }\end{array}$ \\
\hline b. & $\begin{array}{l}\text { No. Unit Kerja } \\
\text { pada Daftar } \\
\text { Distribusi Dokumen belum } \\
\text { sesuai }\end{array}$ & $\begin{array}{l}\text { 2. Lampiran 05, Daftar Distribusi } \\
\text { Dokumen dan Notasi }\end{array}$ & $\begin{array}{l}\text { Agar disesuaikan } \\
\text { No. Unit Kerja pada } \\
\text { Daftar Distribusi } \\
\text { Dokumen dan }\end{array}$ \\
\hline c. & $\begin{array}{l}\text { Sasaran mutu } \\
\text { belum } \\
\text { mencantumkan } \\
\text { tolok ukur } \\
\text { pencapaian yang } \\
\text { sesuai }\end{array}$ & $\begin{array}{l}\text { 3. Lampiran 9.5. Sasaran Mutu } \\
\text { Kegiatan harus ditetapkan } \\
\text { sebagai tolok ukur pencapaian } \\
\text { organisasi yang harus dievaluasi } \\
\text { tingkat pencapaiannya, Sasaran } \\
\text { Mutu Kegiatan ditetapkan } \\
\text { beserta pernyataan bagaimana } \\
\text { cara pencapaian dan bilamana } \\
\text { diperlukan cara mengukur } \\
\text { keberhasilannya }\end{array}$ & $\begin{array}{l}\text { Sasaran mutu agar } \\
\text { mencantumkan } \\
\text { tolok ukur } \\
\text { pencapaian dari } \\
\text { masing-masing } \\
\text { kegiatan }\end{array}$ \\
\hline d. & Organisasi & $\begin{array}{l}\text { 1. Lampiran I, Bab 7.1.2.1.d. : } \\
\text { Struktur Organisasi yaitu bagan } \\
\text { struktur organisasi pelaksanaan } \\
\text { kegiatan }\end{array}$ & $\begin{array}{l}\text { Struktur Organisasi } \\
\text { agar } \\
\text { mencantumkan } 1 \\
\text { hirarki di atasnya }\end{array}$ \\
\hline e. & Struktur Organisasi & $\begin{array}{l}\text { 2. Bab 5.5.12. : Struktur organisasi } \\
\text { pengelola SMMK3L pada } \\
\text { Satuan Kerja PJN dan P2JN }\end{array}$ & $\begin{array}{l}\text { Agar dibuat Struktur } \\
\text { Organisasi } \\
\text { Pengelola SMMK3L } \\
\text { sesuai dengan } \\
\text { Manual SMMK3L }\end{array}$ \\
\hline f. & $\begin{array}{l}\text { Kebutuhan sumber daya } \\
\text { sarana dan prasarana } \\
\text { belum dibuat }\end{array}$ & $\begin{array}{l}\text { 1. Lampiran I, Bab 7.1.2.1.f. : } \\
\text { Kebutuhan Sumber } \\
\text { Manusia dan Sumber } \\
\text { lainnya Daya } \\
\text { memenuhi dalam mutu rangka } \\
\text { dipersyaratkan }\end{array}$ & $\begin{array}{l}\text { Kebutuhan Sumber } \\
\text { Daya Sarana agar } \\
\text { dibuat dan } \\
\text { dilengkapi }\end{array}$ \\
\hline g. & 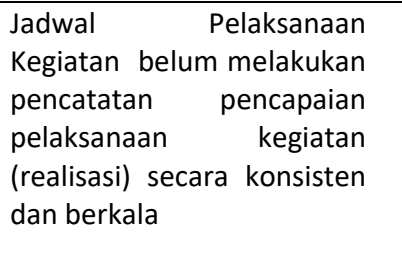 & $\begin{array}{l}\text { 3. Penjelasan lampiran } 9.9 \text { : } \\
\text { Sebagai fungsi kontrol untuk } \\
\text { melakukan evaluasi maka } \\
\text { sedapat mungkin jadwal } \\
\text { kegiatan menyediakan kolom } \\
\text { realisasi untuk pelaksanaan } \\
\text { kegiatannya }\end{array}$ & $\begin{array}{l}\text { Jadwal } \\
\quad \text { pelaksanaa } \\
\text { n kegiatan agar } \\
\text { mencantumkan } \\
\text { kolom realisasi }\end{array}$ \\
\hline
\end{tabular}




\begin{tabular}{|c|c|c|c|}
\hline h. & $\begin{array}{l}\text { Daftar kriteria penerimaan } \\
\text { belum dibuat }\end{array}$ & $\begin{array}{l}\text { 1. Lampiran I, Bab 7.1.2.1.I. : Daftar } \\
\text { Kriteria Penerimaan yaitu } \\
\text { menguraikan ketentuan- } \\
\text { ketentuan dari setiap tahapan } \\
\text { proses dan hasil pekerjaan } \\
\text { sesuai dengan persyaratan } \\
\text { (KAK, spesifikasi teknis, standar } \\
\text { atau peraturan perundang- } \\
\text { undangan) }\end{array}$ & $\begin{array}{l}\text { Daftar kriteria } \\
\text { penerimaan agar } \\
\text { dibuat dan } \\
\text { dilengkapi }\end{array}$ \\
\hline i. & $\begin{array}{l}\text { Daftar Dokumen } \begin{array}{r}\text { Sistem } \\
\text { Mutu }\end{array} \\
\text { melum } \\
\text { mencantumkan dokumen } \\
\text { yang berlaku }\end{array}$ & $\begin{array}{l}\text { 1. Lampiran I, Bab 7.1.2.1.m. : } \\
\text { Daftar Dokumen SMM dalam } \\
\text { rangka mencapai kesesuaian } \\
\text { mutu yang dipersyaratkan }\end{array}$ & $\begin{array}{l}\text { Daftar Dokumen } \\
\text { Sistem Mutu agar } \\
\text { mencantumkan } \\
\text { dokumen yang } \\
\text { berlaku dan } \\
\text { dikendalikan }\end{array}$ \\
\hline
\end{tabular}

\begin{tabular}{|c|c|c|c|c|}
\hline 2. & $\begin{array}{l}\text { RMK KONSULTAN PT. } \\
\text { WESITAN }\end{array}$ & $\begin{array}{l}\text { 1. Permen PU No. } \\
\text { 04/PRT/M/2009 } \\
\text { 2. Petunjuk } \\
\text { Pelaksanaan } \\
\text { Rencana Mutu } \\
\text { Kontrak } \\
\text { DJBM/SMM/PP/1 }\end{array}$ & & \\
\hline a. & $\begin{array}{l}\text { Pengesahan RMK } \\
\text { ditandatangani oleh PPK } \\
\text { bukan oleh Ka. Satker }\end{array}$ & $\begin{array}{l}\text { Konsultan tidak } \\
\text { mengikuti acuan } \\
\text { yang ada }\end{array}$ & $\begin{array}{l}\text { 1. Lampiran IV (Contoh Format } \\
\text { RMK) : Lembar Pengesahan } \\
\text { 2. Bab 5.2 : Untuk Pekerjaan } \\
\text { Konstruksi, RMK diperiksa } \\
\text { oleh PPK dan disahkan oleh } \\
\text { Kepala Satker yang } \\
\text { dipergunakan sebagai } \\
\text { acuan pelaksanaan } \\
\text { kegiatan. }\end{array}$ & $\begin{array}{l}\text { Sesuai dengan } \\
\text { Permen PU No. } \\
\text { 04/PRT/M/2009 } \\
\text { yang mengesahkan } \\
\text { RMK adalah Ka. } \\
\text { Satker bukan PPK. } \\
\text { Oleh sebab itu RMK } \\
\text { agar direvisi sesuai } \\
\text { dengan ketentuan } \\
\text { yang berlaku }\end{array}$ \\
\hline b. & $\begin{array}{l}\text { Sasaran mutu bersifat } \\
\text { umum dan belum } \\
\text { memenuhi kaidah } \\
\text { SMART }\end{array}$ & $\begin{array}{l}\text { Konsultan tidak } \\
\text { memahami lingkup } \\
\text { kegiatan yang telah } \\
\text { dijelaskan dalam } \\
\text { KAK. Akibatnya } \\
\text { sasaran mutu yang } \\
\text { disusun tidak sesuai } \\
\text { dengan lingkup } \\
\text { kegiatan dalam KAK }\end{array}$ & $\begin{array}{l}\text { 1. Lampiran I, Bab } \\
\text { 7.1.3 Sub bab 1.b. } \\
\text { : } \\
\text { Sasaran Mutu yang } \\
\text { menguraikan target } \\
\text { pencapaian mutu yang } \\
\text { terukur sesuai dengan } \\
\text { KAK/RKS; } \\
\text { 2. Bab 5,Sub bab 5.3.4 } \\
\text { tentang Sasaran Mutu } \\
\text { Kegiatan cara } \\
\text { pencapaian dan } \\
\text { bilamana diperlukan cara } \\
\text { mengukur } \\
\text { keberhasilannya. }\end{array}$ & $\begin{array}{l}\text { Agar dibuat sasaran } \\
\text { mutu bagian yang } \\
\text { spesifik dengan } \\
\text { menggunakan } \\
\text { kaidah SMART } \\
\text { (Specific, } \\
\text { Measurable, } \\
\text { Applicable, } \\
\text { Reasonable, Time } \\
\text { Frame), meliputi } \\
\text { metode } \\
\text { pelaksanaan, } \\
\text { sasaran mutu } \\
\text { terhadap input } \\
\text { (sesuai KAK) } \\
\text { persiapan dan } \\
\text { mobilisasi yang } \\
\text { tepat waktu, proses } \\
\text { pelaksana-annya } \\
\text { memenuhi } \\
\text { Spesifikasi } \\
\text { Umum/Khusus, } \\
\text { PP/IK/SOP Kegiatan, } \\
\text { output progres } \\
\text { realisasi dan }\end{array}$ \\
\hline
\end{tabular}




\begin{tabular}{|c|c|c|c|c|}
\hline c. & $\begin{array}{l}\text { Struktur Organisasi } \\
\text { penyedia jasa tidak } \\
\text { mencantumkan hirarkhi } \\
\text { diatasnya }\end{array}$ & $\begin{array}{l}\text { Pemahaman } \\
\text { kontraktor yang } \\
\text { masih kurang }\end{array}$ & $\begin{array}{l}\text { 1. Lampiran IV (Contoh } \\
\text { Format RMK) : Strukutur } \\
\text { Organisasi } \\
\text { 2. Bab 5,Sub bab 5.3.6 } \\
\text { Struktur Organisasi } \\
\text { disajikan dalam bentuk } \\
\text { organigram, lengkap } \\
\text { dengan penjelasan } \\
\text { nama bagian bagiannya, } \\
\text { serta nama pejabatnya serta } \\
\text { garis intruksi maupun garis } \\
\text { koordinasinya dengan } \\
\text { struktur organisasi unit } \\
\text { pelaksana kegiatan; }\end{array}$ & $\begin{array}{l}\text { Bagan Struktur } \\
\text { Organisasi } \\
\text { Penyedia Jasa agar } \\
\text { mencantumkan } \\
\text { hirarki diatasnya }\end{array}$ \\
\hline d. & $\begin{array}{l}\text { Kerangka Acuan Kerja, } \\
\text { Metode Verifikasi, } \\
\text { Validasi, Monitoring, } \\
\text { Evaluasi, Inspeksi dan } \\
\text { Pengujian \& Kriterian } \\
\text { Penerimaan belum ada }\end{array}$ & $\begin{array}{l}\text { Konsultan tidak } \\
\text { faham dan kurang } \\
\text { mengerti }\end{array}$ & $\begin{array}{l}\text { 2. Bab 5, } \\
\text { Sub bab 5.3.15 } \\
\text { Rencana dan Metode } \\
\text { Verifikasi, Validasi, } \\
\text { Monitoring, Evaluasi, } \\
\text { Inspeksi dan Pengujian dan } \\
\text { Kriteria untuk menjamin } \\
\text { bahwa setiap input yang } \\
\text { digunakan adalah } \\
\text { memadai/sesuai } \\
\text { persyaratan, setiap proses } \\
\text { yang dilakukan adalah } \\
\text { sesuai dengan } \\
\text { rencana/sesuai persyaratan } \\
\text { dan produk kegiatan sesuai } \\
\text { dengan } \\
\text { rencana/persyaratan } \\
\text { beserta metode } \\
\text { pemeriksaan dan kriteria } \\
\text { penerimaannya;Penerimaan } \\
\text { nya yaitu menguraikan } \\
\text { rencana kegiatan }\end{array}$ & $\begin{array}{l}\text { Konsultan agar } \\
\text { membuat kerangka } \\
\text { acuan kerja, metode } \\
\text { verifikasi, validasi, } \\
\text { monitoring, evaluasi, } \\
\text { inspeksi dan } \\
\text { pengujian \& kriterian } \\
\text { penerimaan }\end{array}$ \\
\hline
\end{tabular}

\section{Kesimpulan}

Sesuai hasil implementasi uji mutu konstruksi pada paket Pekerjaan Pembangunan Jalan Batas Kecamatan Siding/Seluas-Batas Kecamatan Sekayam/Entikong (MYC) Provinsi Kalimantan Barat adalah sebagai berikut:

1. Pelaksanaan SMM (Sistem Manajemen Mutu) pada rencana mutu pelaksanaan Pejabat Pembuat Komitmen di Paket tersebut perlu perbaikan dan melengkapi dokumen RMP tersebut.. Hal tersebut diwujudkan dalam bentuk kinerja penerapan penyelenggaraan SMM berdasarkan Peraturan Menteri PU No. 04/PRT/M/2009, tanggal 16 Maret 2009, tentang Sistem Manajemen Mutu Departemen Pekerjaan Umum.

2. Rencana Mutu Kegiatan (RMK) Konsultan pengawasan masih perlu perbaikan dan melengkapi kekurangan, seperti sasaran mutu yang bersifat umum dan belum memenuhi kaidah SMART (Specific, Measurable, Applicable, Reasonable, Time Frame)

\section{Referensi}

Peraturan Menteri PU No. 04/PRT/M/2009, tanggal 16 Maret 2009, tentang Sistem Manajemen Mutu Departemen Pekerjaan Umum

Peraturan Menteri No. 38/PRT/M/2007, tentang Pedoman Pola Klasifikasi Arsip Departemen Pekerjaan Umum

Peraturan Menteri PU No. 39/PRT/M/2007, tentang Pedoman Jadwal Retensi Arsip Departemen Pekerjaan Umum

Dokumen Manual Mutu, Direktorat Jenderal Bina Marga No. DJBM/SMM/MM Rev. 01, Tanggal 26 Agustus 2013

Manual Sistem Manajemen Terintegrasi :

(Mutu,Keselamatan Kesehatan Kerja dan Lingkungan), No. MMK3L DJBM/2016. Tanggal 01 Juli 2016 
Kementerian Pekerjaan Umum dan Perumahan Rakyat Direktorat Jenderal Bina Marga, Prosedur Tindakan Perbaikan, SOP/UPM/DJBM-05

Kementerian Pekerjaan Umum dan Perumahan Rakyat Direktorat Jenderal Bina Marga, Prosedur Pengendalian Arsip, SOP/UPM/DJBM-02

Kementerian Pekerjaan Umum dan Perumahan Rakyat Direktorat Jenderal Bina Marga, Prosedur Pengendalian Hasil Pekerjaan /Produk Tidak Sesuai, SOP/UPM/DJBM-04

Kementrian Pekerjaan Umum. 2011. Kebijakan Pemerintah Tentang $K 3$.

Permen PU No: 09/PRT/M/2008. 1 Juli 2008. Jakarta.

Pemerintah Republik Indonesia. 1997. Dasar-dasar K3 Konstruksi. Menteri Tenaga Kerja PERMEN Nomor: PER-05/MEN/1999. Jakarta.

Peraturan Pemerintah No. 5 Tahun 2012 